\author{
Anna KOTASIŃSKA \\ University of Wrocław, Faculty of Social Sciences, Poland
}

\title{
Extension of the Border Fences - Restoring the Past
}

\section{Rozwój barier granicznych - powrót do przeszłości}

\section{- Abstrakt •}

Artykuł przedstawia zagadnienie powrotu do budowy konstrukcji granicznych, które przez naukowców określane jest mianem polityki podziałów lub polityki budowania barier w kontekście poprawy systemów ochrony granic. Zjawisko to może być rozumiane jako przeciwieństwo globalizacji, która przez lata była postrzegana jako proces otwierania się na świat i znoszenia granic. Jest także coraz częściej uznawane za czynnik dzielący społeczeństwa, który zmienia percepcję granic państwowych. Współczesny proces odgradzania się państw koncentruje się na budowie inteligentnych barier. Mogą one w sposób niezauważalny chronić państwo przed rozmaitymi zagrożeniami zewnętrznymi. Artykuł ma na celu dostarczenie teoretycznych podstaw procesu odgradzania oraz pomóc $\mathrm{w}$ znalezieniu odpowiedzi na pytania dotyczące jego przyczyn i przyszłego kierunku rozwoju konstrukcji granicznych.

Słowa kluczowe: bariery graniczne; teoria granicy; proces odgradzania; polityka podziałów; inteligentne bariery

\section{- Abstract •}

The article presents the issue of the return to physical border constructions, what scientists describe as fencing policy, or teichopolitics, in the context of improving the border protection systems. It can be noted as a contrast to globalization, that has been perceived for years as the process of opening to the world and lifting the boundaries. It is also increasingly considered as an element of social bifurcation, which changes the perception of state borders. The contemporary bordering process focuses on the construction of smart fences that can invisibly protect states from emerging various external threats. This article aims to provide a bordering process framework and get answers to the questions about the reasons for this process and future direction of border walls/fences development.

Keywords: border fences; theory of the border; bordering process; fencing policy; smart fences 


\section{Introduction}

"We live in a world of borders" (Nail, 2016, p. 1). With these words, Thomas Nail begins his analysis of the theory of the border in one of his publications. Even though the researchers announced the end of the twentieth century as the development of a world without boundaries subject to the globalization process (e.g., Miyoshi, 1993; Ohmae, 1998), after almost two decades, it can be stated that this vision is a fantasy. Moreover, over the years, new types of borders and reinforcement structures such as razor-wire (barbed-wire) fences, different types of barriers, steel beam vehicle fences, concrete walls with steel mesh, which can be additionally equipped with sensors, trenches, watchtowers, video cameras or thermal imaging, have been created (Nail, 2016, p. 1; Feigenbaum, 2010, p. 120; Saddiki, 2017, p. 13). Even in places that theoretically do not have a physical border barrier, security checkpoints whose main task is to intensify control and increase the level of security are being established all over the world. It is not only border crossings that are the issue, but also roads, airports, schools, enterprises, or housing estates (Nail, 2016, p. 1). In the case of a state, the external nature of the borders and their functions that include limiting the access of various-scale foreign entities to its territory are crucial (Balawajder, 2013, p. 45).

The development of physical border barriers implies the emergence of various scientific publications trying to explain the reasons for this process in the $21^{\text {st }}$ century (Andreas, 2003; Feigenbaum, 2010; Nail, 2016; Newman, 2006; O'Dowd, 2010; Pallister-Wilkins, 2016; Rosière \& Jones, 2012; Saddiki, 2017; Vallet, 2014, etc.). In the most general terms, they state the return or continuation of the creation and implementation of a specific type of policy which, in the context of Said Saddiki's considerations, has been called fencing policy (Saddiki, 2017). It should be referred to the development of border infrastructure based on constantly newer constructions, activities of services and institutions responsible for border security, and the development and implementation of procedures that serve this purpose. Because of similar structural border barriers around the world, the term "globalized fences" has appeared in the scientific literature to define the scale of the occurrence of this phenomenon, which is spreading to other areas in the $21^{\text {st }}$ century (Feigenbaum, 2010, p. 119).

It should be emphasized that, despite the existence of common parts of individual boundary structures, they are not identical and a distinction can be made already at the stage of naming them. Although from the point of view of the real indication that a given construction exists, naming it is less important, the differences between the terms of wall and fence should be noticeable from the 
technical perspective. An example may be the Israeli-Palestinian border, and the related security/anti-terror fence also presented as the separation or apartheid wall (Feigenbaum, 2010, p. 119; Rosière \& Jones, 2012, p. 225). In fact, this structure contains both wall and fence elements but to maintain greater political correctness it is officially referred to by the Israeli side as a fence in diplomatic documents, while opponents unquestionably consider it a wall (Feigenbaum, 2010, p. 119). Historically, one can find even more terms related to the border, like a cell, frontier, limit, boundary, etc. (Nail, 2016, p. 2).

It is not without reason that over the last dozen or so years there has been an increase in the interest of researchers in the subject of borders, although it is difficult to create the only and final theory of border(s) (Newman, 2006, p. 144; Nail, 2016, p. 1). That does not mean, however, that this area of knowledge has not been included in the theoretical framework so far since T. Nail has attempted it. He perceives the border as "an active process of bifurcation that does not simply divide once and for all, but continuously redirects flows of people and things across or away from itself" (Nail, 2016, p. 4). This approach stands in opposition to the recognition of borders as things and their exploration only from a geographical point of view. Contemporary research on the bordering process ought to combine the achievements of geographers, sociologists, anthropologists, lawyers, political scientists, historians, economists, philosophers, and many other scientists to grasp its essence as profoundly as possible - learn its causes and forecast the multifaceted effects of various countries' return to physical separation from their neighbors (Newman, 2006, p. 144). This article attempts to collect the reflections of scientists to get an answer to the questions: Why does the return to the process of bordering take place and what direction will it head in the future? Based on the subject literature and using the method of qualitative content analysis, the article describes the basics of the theory of the border, the change in the perception of boundaries in the era of globalization, and the return to the idea of divisions, including physical ones.

\section{A State Border as "a Process of Social Division"}

From a historical point of view, a border was most often perceived in a military approach (Andreas, 2003, p. 80; Newman, 2003, p. 14; Paasi, 1998, p. 69), i.e., a static representation of a borderline, having a decisive influence on the security of the territory divided by this line and the population living on it. With time, it also gained an economic dimension, thus leading to globalization and the occurrence of 
the phenomenon referred to in the literature as the transition from "the age of empire" through "the era of a nation-state" to "a post-national world" (O’Dowd, 2010, p. 1032). Unfortunately, this process has begun to be identified with the weakening of the importance of national borders that, according to the supporters of globalization, are getting blurred, while leaving aside their separateness and multidimensionality at the same time (O'Dowd, 2010, p. 1032). In fact, the $21^{\text {st }}$ century saw that the opening to the world paradoxically led to the increase in the value of state borders on various levels. This change was noticed by David Newman, who said that "for as long as the study of boundaries was synonymous with the lines separating the sovereign territory of states in the international system, the focus of research was geographical. As our understanding of boundaries has taken on new forms and scales of analysis, so too the study of the bordering phenomenon has become multidisciplinary, with sociologists, political scientist, historians, international lawyers and anthropologists taking an active part in the expanding discourse" (Newman, 2003, p. 16).

It is currently difficult to clearly define what a state border is since each description will be somewhat simplification. The more so that even the perception of the same frontier by different people may be dissimilar. The internal borders within the Schengen area, where disparate rules concerning crossing them apply to the citizens of the Member States and other ones to people outside it, constitute a perfect example of the above. Therefore, their associations will be different, in the case of the first ones - with openness and freedom of movement, while of the other group - with control and impediments. From this viewpoint, the same boundary can be considered only a common obstacle or a physical barrier. A similar situation took place in the past, which is why "we need to overturn the false simplicity of some obvious notions" (Balibar, 2002, p. 76). It is certain that as far as a state is concerned, the border remains in an undeniable connection with the territory which it sets. If the territory is defined as an area located inside a specific border, and the border is considered as nothing else than (simplifying) the line surrounding the territory, logically, the problem of the vicious circle (Latin: circulus in definiendo) appears (Balibar, 2002, p. 76). One solution to this problem may be indicated by T. Nail, who considers this border as "a process of social division" (Nail, 2016, p. 2). Such perception implies - as the author calls it - four consequences that are included in the following statements: "the border is in between", "the borders are in motion", "the border is a process of circulation", and "the border is not reducible to space" (Nail, 2016, pp. 2-9).

The first consequence mentioned by Nail concerns the departure from the traditional perception of the border as an area dividing two separate territories, 
which occurs in the works of many theoreticians, such as Anthony Giddens, Richard Hartshorne or Friedrich Ratzel. The author notes that not only was the border initially a symbol of a social division but also territorially is not part of it, just as the space created after cutting a piece of paper does not belong to any of the two new elements. As Nail notes, "if the border were completely reducible to the two states, nothing would divide them - which can't be true" (Nail, 2016, p. 3). What is precisely between them is the subject of research in the border theory, namely the limit (border) that divides the social space. Hence, its recognition as a continuous division process. The second consequence is the negation of the stability of the boundaries. However, it is not about movement in the sense of moving people or things, but the movement of the border itself in the aspect of geomorphology, territorial changes, purposeful transformations, etc. (Nail, 2016, p. 6). Another concerns the circulation, which allows both accepting everyone into the social space and expelling them back outside. The last one explains that the border cannot be described and understood only from the perspective of its territorial dimension (Nail, 2016, pp. 7-9).

Nail's insights break the static look at the border as a geographical area analyzed in isolation from the social environment, and yet people and increasing their mobility influenced changes in the perception of the dynamic border process. Anssi Paasi similarly approaches the issue, treating "boundaries as complicated social processes and discourses rather than fixed lines" (Paasi, 1998, p. 73). He notes that today it is socio-cultural phenomena, not their territorial dimension, that largely determine changes in the perception of state borders. The roles they play are also changing, which are easier to understand if they begin to be perceived from the perspective of institutions and symbols (Paasi, 1998, p. 72). They can be found in various activities and discourses, regarding culture, politics, economy, and administration (Paasi, 1998, p. 73). Those and other areas of the functioning of a state can be seen, among other things, in the polemic concerning the construction of border structures. Paasi justifies his assumptions considering the Finnish-Russian border, although much more examples can be found in Europe. Borders, symbolism, and institutions mutually intertwine because they are rooted in wider social practice or the very discourse existing within society, remaining in connection with national ideologies and identities (Johnson et al., 2011, p. 63). Complex systems for physical border protection can also be located "everywhere", not only on the territorial peripheries (Johnson et al., 2011, p. 63).

The above examples reflect the transformation of the perception of boundaries and a departure from the static approach to them towards research on their social dimension. Furthermore, D. Newman also treats the border as a dynamic 
institution and adds that "it is the process of bordering, rather than the borderline per se, that has universal significance in the ordering of society" (Newman, 2003, p. 15). Étienne Balibar approaches the issue in a dualistic way while noting, on the one hand, "the institution of the border (...) and the ways in which borders can be instituted", and, on the other, "the border as a condition of possibility of a whole host of institutions" (Balibar, 2002, p. 84).

In the context of the fencing policy development, even the most basic, geographical (spatial) perception of the border has significantly changed after countries began to create constructions that isolate them from their neighbors also underground, in the air or at sea. An excellent example is the State of Israel, separated from other countries at every possible level. The above constitutes the negation that the border is taken only as a plane perpendicular to the surface of the earth (Balawajder, 2013, p. 46). It also questions the conviction that the divisions are becoming blurred as the integration process progresses (Balawajder, 2013, p. 48). The intensification of economic exchange or the increase of freedom of movement of people in Europe did not affect the abolition of all restrictions, which seems to be particularly noticeable in the case of countries that decide to create border guards in the protection against the inflow of illegal immigrants or members of foreign intelligence (Kotasińska, 2017a).

Differentiated perception of the borders and bordering process create obstacles to the formulation of the universal theory of the border. Paasi's words confirm that: "There can hardly be one grand theory that would be valid for all borders. Such a theory is not problematic because the borders are unique but rather because of the complexity of borders and bordering" (Johnson et al., 2011, p. 62). Nevertheless, one should mention the attempts made by T. Nail, who developed his border theory and border methodology to set some theoretical framework. They allow determining historical conditions affecting the appearance of real boundaries in various social contexts. Hence the goal of the researcher is to establish the basis for the analysis of "four major social and material types of borders: territorial, political, juridical and economic" (Nail, 2016, p. 12). The method created by Nail, called "critical limology", is to serve the implementation of his assumptions by enabling the identification of the conditions for creating such borders, also in relation to old and modern border technologies, which are particularly important from the perspective of this article (Nail, 2016, p. 14). 


\section{A World Without Borders and the Process of Globalization}

The end of the $20^{\text {th }}$ century is associated with the fading of the Cold War period, the disintegration of many countries into smaller entities (such as the Union of Soviet Socialist Republics or the Socialist Federal Republic of Yugoslavia), and finally the demolition of the Berlin Wall. All these events heralded the arrival of numerous changes that were aimed at increasing the transparency of states' activities, their opening up to peaceful cooperation and focusing on soft power as a group of measures serving the implementation of foreign policy. They also coincided in time with the extreme acceleration of the globalization processes, which influenced the gradual abolition of economic, commercial, informational, political (belonging to various international organizations), educational, and cultural barriers. Therefore, it does not come as a surprise that with the elapse of time, predicting the decline in the significance of state boundaries began, eventually reaching the moment when the geographical divisions will be abolished. As Henry Wai-Chung Yeung pointed out: "the globalization (...) has led us to think that we are entering a 'borderless' world" (Yeung, 1998, p. 291). However, in fact, "borderless" is primarily about the world market, which has indeed been significantly transformed (Moore, 2003; Ohmae, 1998; Paasi, 1998; Yeung, 1998). According to Amin and Thrift, "globalisation does not represent the end of territorial distinctions and distinctiveness, but an added set of influences on local economic identities and development capabilities" (Amin \& Thrift, 1994, p. 2). This notion gained the broader dimension at the beginning of the $21^{\text {st }}$ century in Europe, when integration trends on this continent intensified and were to lead to the creation of common, open space (Newman, 2003, p. 19).

Two main assumptions that accompanied the spread of globalization can be indicated: the increase in the anachronism of physical border barriers (such as fences or walls) and the growth of freedom of movement of people, goods, capital and information (Rosière \& Jones, 2012, p. 217; Newman, 2003, p. 18). However, the effects of this "opening" to the world were not predicted. In North America, September 11, 2001, turned out to be the breakthrough moment since then the perception of state security and the protection of its borders changed. Fear of further terrorist attacks instilled in people distrust and increased the need to control immigrants or transported goods. Europe saw the illusion of the borderless world over a decade later while facing an uncontrolled influx of immigrants from Africa and the Middle East. "When it comes to migration, there is no government in this world that brings the much celebrated rhetoric of a borderless world into actual 
practice" (Van Houtum \& Van Naerssen, 2002, p. 127), what for several years has been particularly confirmed in the activities of some European countries. What is more, according to Wendy Brown, the emergence of new border barriers in the world may indirectly be the result of globalization and constitute an expression of opposition to the pressure exerted on the states and nations by this process (Brown, 2010, p. 27). These constructions arise and function even when their effectiveness is doubtful because they are a response to the needs of societies whose sense of physical and socio-economic security is xenophobic (Brown, 2010, p. 69). "We should recognize the qualitative and dialectical nature of globalization and its key actors, in order to understand and explain the world in which we are living" (Yeung, 1998, p. 304).

There is no doubt that the intensification of globalization at the threshold of the second millennium has removed some barriers. Interestingly, the same force (universal access to information) that made people open to "others" (Newman, 2003, p. 21) and made it possible to get to know their culture, traditions, and surroundings without leaving home, later led to the appearance of prejudices and even antagonisms. It is easy to imagine a change in the perception of Arabs by members of societies affected by terrorist attacks or uncontrolled influx of people, even though they were accepted not so long ago and their culture aroused admiration and curiosity among foreigners. Changes in access to information have also led to the development of cybercrime, where global systems (e.g., banking), countries, and even individuals may fall its victims. Twenty years ago, it was anticipated in the context of globalization that "this process will reduce the roles of the sovereignty and identities of states and therefore also challenge national identities and boundaries" (Paasi, 1998, p. 71). Today's return to physical barriers may be an expression of the states' struggle for a return to their former state.

It can be concluded that globalization should not be considered as a premise to remove state borders, but as a kind of reason to strengthen physical divisions. This process continually puts states in the face of new opportunities, challenges, and threats for which not all entities were and are prepared. The openness to the world associated with universal access to information, stimulation of trade and international cooperation at various levels is positively associated. Nonetheless, pejorative associations increasingly appear as well. They concern, among other things, the necessity of colliding with a foreign culture and the flow of people, which can never be fully controlled, to predict whether it poses a threat to the state and/or its citizens. "What we have come to call globalization harbors fundamental tensions between opening and barricading, between fusion and partition, between erasure and reinscription (...) between global networks and local nationalisms, between 
virtual power and physical power, between private appropriation and open sourcing, secrecy and transparency, territorialization and deterritorialization. One place that these tensions nest is in the new walls striating the globe" (Brown, 2010, p. 8).

\section{Contemporary Fencing Policy - Return to Divisions}

The beginnings of the construction of boundary and defense walls date back to the period of 6000-8000 BCE, while the development of metal fences, including those finished with barbed wire, falls only to the $19^{\text {th }}$ century (Feigenbaum, 2010, p. 121). Both can be considered as expressions of care for safety, a means of exerting influence, and even a manifestation of strength. Historical examples of wall power are Hadrian's Wall and Great Wall of China (Nail, 2016, p. 8; Rosière $\&$ Jones, 2012, p. 220). According to Anna Feigenbaum, similar functions are performed by "globalized fences", namely border constructions occurring as artifacts of globalization (Feigenbaum, 2010, p. 119). Four common features have been distinguished for them: "they serve transnational security functions (...), they are contracted through multinational companies, they are built with materials imported from different nations, and they integrate 'virtual' and physical technologies" (Feigenbaum, 2010, p. 121).

The final development of modern border technologies is related to the evolution of cross-border activities, especially illegal ones, as well as newly emerging threats (Saddiki, 2017, p. 1). According to Saddiki, these barriers also express economic disparities between countries. That stems from the fact that richer entities decide to build them, which is a physical obstacle for illegal immigrants coming from less developed countries, thereby "a frontier of poverty" is designated. It is exemplified by the American-Mexican border, which in a sense can be considered a manifestation of lack of agreement between a stronger and a weaker state actor and the imposition of the stronger party's will. It is worth noting that US cooperation with a more affluent neighbor to the north - Canada - is quite different (Saddiki, 2017, p. 4). In the context of the countries (the USA, Israel) exerting pressure on the weaker entity (Mexico, Palestine) taking advantage of the constructed boundary wall, Brown uses the term of "Walled States" or "Walled Democracies" (Brown, 2010).

The turn of the ages not only has not brought the development of a world without borders, as was trumpeted by many, but it has also repeatedly upheld the existing divisions expressed by the existence of border constructions. Listing all 
examples of border structures currently in operation is impossible. In the scientific literature, one can find even several dozens of them (Rosière \& Jones, 2012, p. 223; Saddiki, 2017, pp. 4-5). In 2002, Naomi Klein wrote: "And yet thirteen years after the celebrated collapse of the Berlin Wall, we are surrounded by fences yet again, cut off - from one another, from the earth and from our own ability to imagine that change is possible" (Klein, 2002, p. XX). Fences that are increasingly dividing states. Although in contemporary border studies the significance of state borders is diminishing, Europe is indicated as an example of the transition to the era of post-nationalism (O'Dowd, 2010, p. 1033). It is there where the barriers take on a mental character and a return to physical divisions, but much more technologically advanced, has been observed for several years. All this is unquestionably connected with border security issues and indicates an important research area (Kotasińska, 2017a, p. 98).

As D. Newman points out, "the essence of a border is to separate the 'self' from the "other"' (Newman, 2003, p. 14). It can, therefore, be a manifestation of an opposite process to globalization (Rosière \& Jones, 2012, p. 220), but technologization is the factor that connects these two opposing forces. On the one hand, in a narrower sense, it means an improvement of technical facilities so that they are capable of counteracting emerging threats. On the other hand, it should be perceived in a broader context - the involvement of people and the evolution of systems (social, economic and cultural ones) that determine the development of technology (Feigenbaum, 2010, p. 123). The "fencing policy" according to Saddiki and "teichopolitics" according to Rosière and Jones - perceived as "the politics of building barriers on borders for various security purposes" (Rosière \& Jones, 2012, p. 219) - comprise the entirety of activities aimed at improving the border protection systems.

Rosière and Jones introduced the typology of modern border constructions, dividing them into frontlines, fences/walls, and closed straights. The first category constituted (following the data from 2012) 13\% of all border fortifications in the world and refers to the demilitarized zone, i.e., the strip of no man's land separating the two lines of the front. The longest of them divides Morocco and Western Sahara, although it can also be found on the Korean Peninsula or between India and Pakistan (Rosière \& Jones, 2012, pp. 222-223). Nearly all the rest of the structures (about 87\%) are fences and walls as the most symbolic expression of the construction created within the framework of teichopolitics. One of the best known and described examples (e.g., Alvarez, 1995; Andreas, 2003; Avdan \& Gelpi, 2017; Feigenbaum, 2010; Johnson et al., 2011; Newman, 2006; Rosière \& Jones, 2012; Saddiki, 2017) is between the US and Mexico, and its building 
was initiated as early as in 1996 in connection with the adoption of the Illegal Immigration Reform and Immigrant Responsibility Act (Kotasińska, 2017b, p. 118). It took place already after the fall of the Berlin Wall, which was to be a harbinger of the abolition of physical divisions between states after the Cold War, which was undoubtedly a period of uncertainty. The turn of the century brought new threats, and with them, the need to counter terrorism, smuggling or illegal immigration arose, expressed by the state walls and fences.

The last group is represented by closed maritime straights, particularly crucial for controlling the flow of the migrating population, though not comparable with the previous groups. Among them, researchers mention the Strait of Florida, the Gibraltar Strait, and the Arafura and Timor Seas. "Such straits consist of a virtual fence implemented on the immigration side (the wealthy coast) and are organized around control towers to which various alarm systems, satellite, radar, and airplane reconnaissance are connected" (Rosière $\&$ Jones, 2012, p. 227). They allow patrolling waters in search of unauthorized boats and intercepting them by competent services before reaching land. Thus, the task of teichopolitics is not to lift borders, but to clarify their control as an action not only for security but also for the global economy (Rosière \& Jones, 2012, p. 227). This, in turn, is associated with the development of modern technologies, which has been mainly realized in the activities of the State of Israel, which emphasizes the continuous development of border systems, and even their export to other countries, including European ones, of which the mainly Elbit System and the Magal Security Systems are particularly well known Israeli companies. "Since 2002, exports of Israeli technology in border security services increased by 22 percent each year, and there are about 450 Israeli companies specializing in securing territory" (Saddiki, 2017, p. 5). That is an impressive result for such a small state and reflects the deliberately created policy of Israel, leading to separation from all neighbors. The most well-known and the oldest part of the border structures erected by this state is a heterogeneous installation consisting of the "security wall" on the West Bank line (Avdan \& Gelpi, 2017; Newman, 2006; Pallister-Wilkins, 2016; Saddiki, 2017). The initiation of the construction of its above-ground part in 2002 led to the interruption of the peace process and the beginning of a period of permanent separation. However, this was not enough for the Israeli side, which is why the construction of an underground part of the barrier commenced and aimed at destroying the underground tunnels of Hamas (Kotasińska, 2017c, p. 132).

Israel did not stop with building the "security wall". It finally separated itself from Egypt in 2013, from Lebanon in 2001. It has undergone many transformations since then, as was the case with the construction on the Syrian border, the re- 
construction of which was decided in 2012. The extension of the Egyptian section was to constitute a modern installation on the border with Jordan, and the Israeli authorities announced its construction in 2015 (Kotasińska, 2017c, pp. 133-134). It should be remembered that the completion of individual fragments of the Israeli "border isolation" did not mean the end of the work and in the subsequent years, there were transformations aimed at creating smart fences (Blank, 2011, p. 313; Feigenbaum, 2010, p. 123; Rynhold, 2004, p. 62). That was followed by other countries, such as the USA (Saddiki, 2017, p. 89) or India (Feigenbaum, 2010, p. 123), which also began to establish similar border structures. The use of advanced technologies enabled the reduction of costs allocated to the construction of physical fortifications and the focus on virtual solutions. Currently, it is common to use unmanned aerial vehicles, monitoring, various types of sensors (of traffic or heat) and even unmanned patrol vehicles (Kotasińska, 2017c, p. 132), thus limiting the number of guards and the fences/walls, which cannot be built everywhere (Feigenbaum, 2010, pp. 122-123). This type of "invisible" barriers may become a future domain in many countries and their smart borders a counterweight to physical constructions that express hard power (Amoore, Marmura, \& Salter, 2008, p. 99; Rosière \& Jones, 2012, p. 226).

An interesting phenomenon is also the use of Israeli technologies (primarily) by the countries of Europe, which because of the uncontrolled influx of immigrants faced the need to seek new solutions to this problem. It was made particularly visible in 2015 (Dingott Alkopher \& Blanc, 2017, p. 511), although already at the beginning of 2012 Greece announced a decision regarding the construction of a border barrier along the section of the external border of the European Union and the Schengen area (Kotasińska, 2017a, p. 101). This decision triggered a chain reaction in other countries to which the population searching of a new route to Europe began to arrive. A year after Greece, the establishment of a border installation was decided by Bulgaria, followed by Macedonia and other countries from the Balkan Route, which along the Mediterranean Route is the second main corridor for migration of people from the south (Biernat, 2015, p. 1). In the years 2015-2016, countries such as Slovenia, Hungary and Austria also turned towards the fencing policy (Kotasińska, 2017a, p. 102). An interesting phenomenon was the inclusion of the Baltic states into the group, specifically Lithuania, Latvia and Estonia, which were constructing the "Baltic wall" (Janczys, 2017). In fact, it is rather a fence equipped with modern technologies that are to help intercept persons associated with the Russian special services (intelligence services). These are mainly illegal migrants and members of organized criminal groups (Janczys, 2017). All these activities make it possible to note the transition from "borders" to 
"bordering practices" (Vaughan-Williams, 2015, p. 6) also in Europe, expressed first and foremost by constructing further border defenses, also changing the perception of state security.

\section{Conclusion}

From the perspective of the information presented in the article, it should be stated that the fencing policy is developing and spreading to other countries. We can assume, that in the future "the wealthy areas of the world can increasingly be viewed as 'off-shore' islands of development protected by walls and fences in an ocean of poverty" (Rosière \& Jones, 2012, p. 231). Therefore, a new look at the bordering process and bordering practices is needed, which more and more frequently combine the emphasis of territorial separateness and socio-cultural factors, especially in the face of the immigration of representatives of different cultures to Europe. That means both a return to understanding borders as a territorial limitation of sovereign states and the development of new functions related to the existence of mental barriers.

This approach suggests "bringing history back in" (O’Dowd, 2010) when walls were built to protect the territory against various external threats. It means a departure from diplomatic means and a return to the cult of strength, even though globalization was to constitute a new stage in the history of humankind - the transition from the war hard power to soft power, from the Cold War uncertainty to the growth of trust and openness to the world. In fact, it did not bring the balanced and stable development of all countries but deepened the disproportions, from which more prosperous entities try to cut off with walls or border fences for the sake of pursuing their interests and protection against foreign influences. Unfortunately, there are no indications that this trend would change over the next few years.

\section{References:}

Alvarez Jr, R.R. (1995). The Mexican-US Border: The Making of an Anthropology of Borderlands. Annual Review of Anthropology, 24(1), 447-470. DOI: https://doi. org/10.1146/annurev.an.24.100195.002311.

Amin, A., \& Thrift, N.J. (1994). Living In the Global. In: A. Amin, \& N.J. Thrift (eds.). Globalization, Institutions, and Regional Development in Europe (pp. 1-22). Oxford: Oxford University Press. 
Amoore, L., Marmura, S., \& Salter, M.B.B. (2008). Editorial: Smart Borders and Mobilities: Spaces, Zones, Enclosures. Surveillance \& Society, 5(2), 96-101. DOI: https://doi. org/10.24908/ss.v5i2.3429.

Andreas, P. (2003). Redrawing the Line: Borders and Security in the Twenty-First Century. International Security, 28(2), 78-111.

Avdan, N., \& Gelpi, C.F. (2017). Do Good Fences Make Good Neighbors? Border Barriers and the Transnational Flow of Terrorist Violence. International Studies Quarterly, 61(1), 14-27. DOI: https://doi.org/10.1093/isq/sqw042.

Balawajder, G. (2013). Granica państwa jako kategoria wielowymiarowa. Pogranicze. Polish Borderlands Studies, 1(1), 44-56.

Balibar, É. (2002). Politics and the Other Scene. London-New York: Verso.

Biernat, A. (2015). Bałkany wobec kryzysu migracyjnego. Putaski Policy Papers. Komentarz Międzynarodowy Putaskiego, 1-8. Retrieved from: https://pulaski.pl/wp-content/ uploads/2015/02/Pulaski_Policy_Papers_Nr_20_15_.pdf.

Blank, Y. (2011). Legalizing the Barrier: The Legality and Materiality of the Israel/Palestine Separation Barrier. Texas International Law Journal, 46(2), 309-343.

Brown, W. (2010). Walled States, Waning Sovereignty. New York: Zone Books.

Datta, A. (2018). Barbed Wire Border Fencing: Exclusion and Displacement at the Indo-Bangladesh Borderland. India Quarterly: A Journal of International Affairs, 74(1), 42-60. DOI: https://doi.org/10.1177/0974928417749640.

Dingott Alkopher, T., \& Blanc, E. (2017). Schengen Area Shaken: The Impact of Immigration-Related Threat Perceptions on the European Security Community. Journal of International Relations and Development, 20(3), 511-542. DOI: https://doi. org/10.1057/s41268-016-0005-9.

Feigenbaum, A. (2010). Concrete Needs No Metaphor: Globalized Fences as Sites of Political Struggle. Ephemera, 10(2), 119-133.

Ferguson, Y.H., \& Mansbach, R.W. (2012). Globalization: The Return of Borders to a Borderless World? Abington: Routledge.

Janczys, W. (2017). Mur battycki. Litwa, Eotwa i Estonia odgradzaja się od Rosji. Retrieved from: https://www.defence24.pl/mur-baltycki-litwa-lotwa-i-estonia-odgradzaja-sie-od-rosji-reportaz.

Johnson, C., Jones, R., Paasi, A., Amoore, L., Mountz, A., Salter, M., \& Rumford, C. (2011). Interventions on Rethinking "The Border" in Border Studies. Political Geography, 30(2), 61-69. DOI: http://dx.doi.org/10.1016/j.polgeo.2011.01.002.

Klein, N. (2002). Fences and Windows: Dispatches from the Front Lines of the Globalization Debate. New York: Picador.

Kotasińska, A. (2016). Pogranicze amerykańsko-meksykańskie i wielopłaszczyznowy problem korupcji. Pogranicze. Polish Borderlands Studies, 4(2), 215-228.

Kotasińska, A. (2017a). „Fencing policy” w polityce wybranych państw świata - wprowadzenie. In: M. Bodziany (ed.). Kryzysy spoteczne XXI wieku. Między dezintegracja, "fencing policy" a upadkiem państwowości (pp. 97-104). Wrocław: Wydawnictwo Akademii Wojsk Lądowych. 
Kotasińska, A. (2017b). Amerykańsko-meksykańska bariera graniczna. In: M. Bodziany (ed.). Kryzysy spoteczne XXI wieku. Między dezintegracja, "fencing policy" a upadkiem państwowości (pp. 117-127). Wrocław: Wydawnictwo Akademii Wojsk Lądowych.

Kotasińska, A. (2017c). Izraelska polityka izolowania się. In: M. Bodziany (ed.). Kryzysy spoteczne XXI wieku. Między dezintegracja, "fencing policy" a upadkiem państwowości (pp. 128-138). Wrocław: Wydawnictwo Akademii Wojsk Lądowych.

Miyoshi, M. (1993). A Borderless World, From Colonialism to Transnationalism and the Decline of the Nation-State. Critical Inquiry, 19(4), 726-751. DOI: http://dx.doi. org/10.1086/448695.

Moore, M. (2003). A World Without Walls: Freedom, Development, Free Trade and Global Governance. Cambridge: Cambridge University Press.

Nail, T. (2016). Theory of the Border. Oxford-New York: Oxford University Press.

Newman, D. (2003). On Borders and Power: A Theoretical Framework. Journal of Borderlands Studies, 18(1), 13-25. DOI: https://doi.org/10.1080/08865655.2003.9695598.

Newman, D. (2006). The Lines That Continue to Separate Us: Borders in Our "Borderless" World. Progress in Human Geography, 30(2), 143-161. DOI: https://doi. org/10.1191/0309132506ph599xx.

Newman, D., \& Paasi, A. (2013). Podziały i sąsiedztwa w ponowoczesnym świecie. Narracje granic w geografii politycznej. Trans. B. Czepil. Pogranicze. Polish Borderlands Studies, 1(1), 12-34.

O’Dowd, L. (2010). From a "Borderless World" to a "World of Borders": 'Bringing History Back in'. Environment and Planning D: Society and Space, 28(6), 1031-1050. DOI: https://doi.org/10.1068/d2009.

Ohmae, K. (1998). The Borderless World: Power and Strategy in the Global Marketplace. London: Profile Books.

Paasi, A. (1998). Boundaries as Social Processes: Territoriality in the World of Flows. Geopolitics, 3(1), 69-88. DOI: https://doi.org/10.1080/14650049808407608.

Pallister-Wilkins, P. (2016). How Walls Do Work: Security Barriers as Devices of Interruption and Data Capture. Security Dialogue, 47(2), 151-164. DOI: https://doi. org/10.1177/0967010615615729.

Rosière, S., \& Jones, R. (2012). Teichopolitics: Re-considering Globalisation Through the Role of Walls and Fences. Geopolitics, 17(1), 217-234. DOI: http://dx.doi.org/10.108 $0 / 14650045.2011 .574653$.

Rynhold, J. (2004). Israel's Fence: Can Separation Make Better Neighbours? Survival, 46(1), 55-76. DOI: https://doi.org/10.1080/00396330412331343663.

Saddiki, S. (2017). World of Walls: Structure, Roles and Effectiveness of Separation Barriers. Cambridge: Open Book Publishers.

Vallet, E. (ed.). (2014). Borders, Fences and Walls: State of Insecurity? Burlington: Ashgate Publishing.

Van Houtum, H., \& Van Naerssen, T. (2002). Bordering, Ordering and Othering. Tijdschrift voor Economische en Sociale Geografie, 93(2), 125-136. DOI: https://doi. org/10.1111/1467-9663.00189. 
Vaughan-Williams, N. (2015). Europe's Border Crisis: Biopolitical Security and Beyond. Oxford: Oxford University Press.

Wastl-Walter, D. (ed.). (2016). The Ashgate Research Companion to Border Studies. London-New York: Routledge.

Yeung, H.W.C. (1998). Capital, State and Space: Contesting the Borderless World. Transactions of the Institute of British Geographers, 23(3), 291-309. DOI: 10.1111/j.00202754.1998.00291.x.

Zureik, E., \& Salter, M.B. (eds.). (2012). Global Surveillance and Policing: Borders, Security, Identity. London-New York: Routledge. 